\title{
ANALISIS EFEKTIVITAS RETRIBUSI PARKIR DAN KONTRIBUSINYA TERHADAP PENDAPATAN ASLI DAERAH PADA DINAS PENDAPATAN DAERAH KOTA KUPANG
}

\author{
Mahalia Lolita Maisal *, Nonce F. Tuati**
}

\begin{abstract}
Abstrak
Penyelengaraan perparkiran membawa dampak penguatan pendapatan daerah melalui retribusi, dimana retribusi parkir untuk pemerintah Kota Kupang merupakan salah satu sumber pendapatan yang potensial untuk membiayai pembangunan kota. Dengan semakin berkembangnya pembangunan, pertumbuhan penduduk, peningkatan jumlah kendaraan bermotor dan mobilitas masyarakatnya yang tinggi maka jumlah objek parkir dan retribusi parkir kendaraan juga meningkat. Tingkat kontribusi retribusi parkir terhadap Pendapatan Asli Kota Kupang masih sangat kecil dan masuk dalam kategori "Relatif tidak memiliki kontribusi" terhadap pendapatan asli daerah. Dinas Pendapatan Daerah Kota Kupang dan dinas (SKPD) yang terkait dibidang retribusi parkir dapat melakukan sosialisasi kepada masyarakat tentang pentingnya membayar parkir dengan tujuan menjadi pemasukan/pendapatan untuk daerah kota kupang.
\end{abstract}

\section{Kata Kunci : Efektivitas, Retribusi Parkir, Kontribusi, Pendapatan Asli Daerah \\ *) Mahalia Lolita Maisal; Alumni Mahasiswa Program Studi Akuntansi Sektor Publik Politeknik Negeri Kupang. **) Nonce F. Tuati; Dosen Program Studi Akuntansi Sektor Publik Politeknik Negeri Kupang.}

\section{PENDAHULUAN}

Kota Kupang merupakan ibu kota provinsi Nusa Tenggara Timur yang bisa di katakan sebagai salah satu kota yang mulai berkembang dan mobilitas penduduknya tinggi. Kota Kupang yang merupakan ibu Kota Provinsi Nusa Tenggara Timur, setiap tahunnya terus dipadati pendatang baik itu wisatawan maupun pelajar dan mahasiswa dari berbagai kabupaten di Nusa Tenggara Timur. Situasi ini menjadikan kota ini berkembang pesat ditambah dengan terus berkembangnya tempat hiburan dan pusat perbelanjaan semakin menambah kepadatan kota. Kepadatan dan mobilitas penduduk yang tinggi menjadikan kebutuhan masyarakatnya semakin kompleks terutama mengenai sarana dan prasarana transportasi umum. bagi pemilik kendaraan yang menginginkan kendarannya dapat parkir di tempat yang mudah dicapai ,salah satunya adalah di tepi jalan umum. Parkir di tepi jalan adalah parkir yang berada pada

\section{POLITEKNIK NEGERI KUPANG}


badan jalan. Perpakiran merupakan subsistem dari sistem besar dari pengelolaan transportasi, yang idealnya merupakan bagian dari solusi dari sistem transportasi. Tapi yang terjadi malah sebaliknya, perparkiran justru menjadi part of the problem dari sistem transportasi itu sendiri. Namun demikian, penyediaan ruang dan jasa parkir di sisi lain memberikan kontribusi positif terhadap keuangan daerah yaitu sebagai penambah penerimaan daerah melalui retribusi parkir di tepi jalan umum yang merupakan salah satu sumber pendaparan asli daerah.

Pemerintah daerah mempunyai tugas dan tanggung jawab dalam membina pengelolaan perparkiran di wilayahnya, yang merupakan bagian dari fungsi pelayanan umum, sebagai imbalan penyelenggaraan pelayanan umum, pemerintah berhak memungut dana dari masyarakat dalam bentuk retribusi sebagai salah satu sumber pendapatan asli daerah (PAD). Dari data awal yang peneliti dapatkan tentang jumlah Pendapatan asli daerah dan retribusi daerah selama tahun 2009-2013 yaitu :

\begin{tabular}{cccc}
\hline 2010 & 259.849 .900 & 10.237 .26 & $36.828 .891 .454,35$ \\
& & 2.522 & \\
\hline 2011 & 299.800 .500 & 11.267 .45 & $47.702 .927 .427,60$ \\
& & 8.193 & \\
2012 & 526.157 .500 & 17.399 .79 & $66.035 .428 .092,83$ \\
& & 3.035 & \\
\hline 2013 & 700.816 .600 & 21.593 .94 & $80.755 .471 .988,14$ \\
& & 2.764 &
\end{tabular}

Sumber : Dinas Pendapatan Daerah Kota Kupang 2014

Tabel 1.2

Data Target dan Realisasi Retribusi Parkir Kota Kupang Tahun 2009-2013

\begin{tabular}{cc|c}
$\begin{array}{c}\text { Tahun } \\
2009\end{array}$ & $\begin{array}{c}\text { Target Penerimaan } \\
\text { Retribusi Parkir } \\
281.750 .000\end{array}$ & $\begin{array}{c}\text { Realisasi } \\
\text { Retribusi Parkir } \\
223.129 .000\end{array}$ \\
2010 & 282.015 .000 & 259.849 .900 \\
\hline 2011 & 400.000 .000 & 299.800 .500 \\
2012 & 410.000 .000 & 526.157 .500 \\
\hline 2013 & 640.000 .000 & 700.816 .600 \\
& &
\end{tabular}

Sumber : Dinas Pendapatan Daerah Kota Kupang 2014

Dilihat dari data pada diatas menunjukan bahwa Pendapatan Asli Daerah Kota Kupang setiap tahunnya selalu meningkat, karena laju pertumbuhan dan ekonomi masyarakan yang tinggi di kota ini. Penerimaan retribusi yang terdapat di Kota Kupang berpotensi dalam meningkatkan pendapatan asli daerah. Sedangkan lewat sektor retribusi daerah khususnya dari retribusi parkir, dalam tiga 
tahun 2009-2011 tidak mencapai target yang di tetapkan dan untuk tahun 2012 dan 2013 retribusi parkir yang diterima atau terealisasi dapat memenuhi target yang ditetapkan oleh pemerintah.

Berdasarkan pada latar belakang tersebut penulis tertarik untuk mengadakan penelitian dengan mengambil judul "Analisis Efektivitas Retribusi Parkir dan Kontribusinya Terhadap Pendapatan Asli Daerah Pada Dinas Pendapatan Daerah Kota Kupang".

\section{KERANGKA BERPIKIR}

Salah satu sumber pendapatan asli daerah ialah dari kontribusi retribusi parkir di tepi jalan umum guna menjalankan roda pemerintahan, oleh karena itu seluruh jumlah retribusi parkir di tepi jalan umum yang dikelola dan diperoleh oleh pemerintah harus di realisasikan dengan benar agar sesuai dengan target yang ditetapkan. Sehingga dengan begitu dapat dilihat seberapa besar kontribusi retribusi parkir serta seberapa tingkat efektivitas retribusi parkir setiap tahunnya terhadap Pendapatan Asli Daerah . Untuk memperjelas alur pemikiran dan lebih memudahkan penelitian maka penulis membuat kerangka berpikir sebagai berikut :

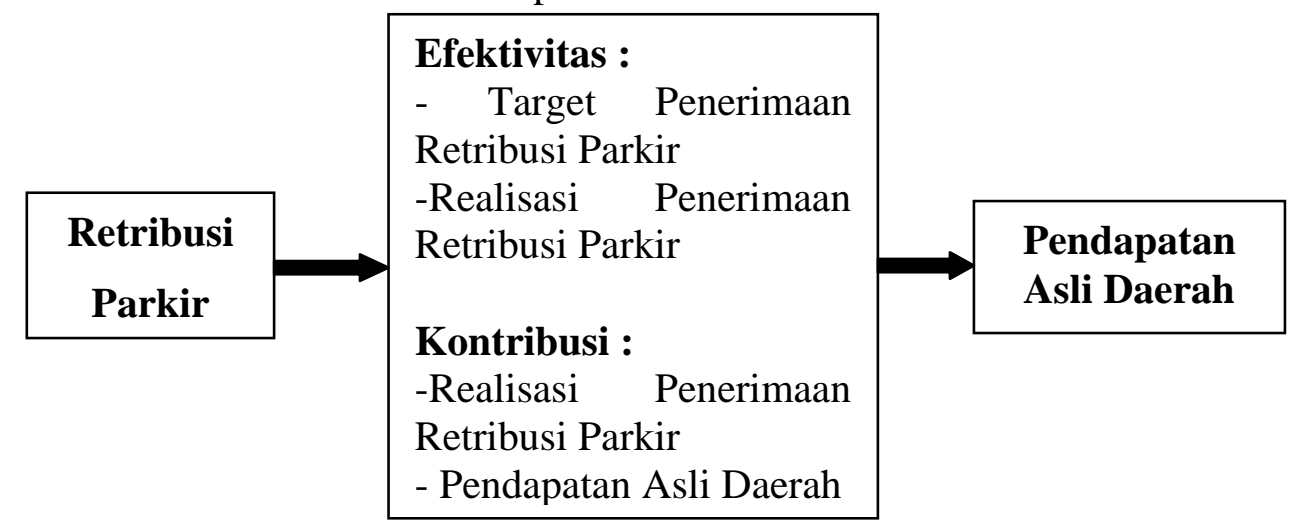

Gambar 2.1

Hipotesis

Skema Kerangka Berpikir

Berdasarkan uraian latar belakang, maka penulis mencoba untuk memberikan sebuah hipotesis sebagai berikut : "Jika Penerimaan Retribusi Parkir yang direalisasikan sesuai dengan target yang ditetapkan, maka tingkat efektivitas dan kontribusi dari retribusi parkir terhadap
Pendapatan Asli Daerah (PAD) pun akan sesuai dengan yang diharapkan".

\section{METODOLOGI PENELITIAN}

Dalam penelitian ini, objek yang diteliti ialah efektivitas dan kontribusi penerimaan retribusi parkir terhadap Pendapatan Asli Daerah Kota Kupang 
Tahun 2009-2013. Jenis Data yang penelitian ini adalah menggunakan metode digunakan adalah data kuantitatif dan data desktiptif kuantitatif.

data kualitatif. Sumber data yang digunakan adalah data primer dan data sekunder. Teknik Pengumpulan Data menggunakan penelitian kepustakaan, penelitian lapangan dan dokumen. Teknik Pada penelitian ini, peneliti menggunakan atau metode analisa untuk kepentingan perhitungan sebagai berikut:

\section{HASIL PENELITIAN}

DAN

\section{PEMBAHASAN}

Perhitungan Efektivitas retribusi Parkir

$$
\text { Efektivitas : } \frac{\text { Realisasi Penerimaan Retribusi Parkir }}{\text { Target Penerimaan Retribusi Parkir }} \times 100 \%
$$

Presentasi Efektifitas

Diatas $100 \%$

$90 \%-100 \%$

$80 \%-90 \%$

$60 \%-80 \%$

Kurang Dari 60\%
Kriteria Efektifitas

Sangat Efektif

Efektif

Cukup Efektif

Kurang Efektif

Tidak Efektif

Perhitungan Kontribusi retribusi Parkir

Kontribusi Retribusi Parkir terhadap PAD : $\frac{\mathrm{x}}{\mathrm{z}} \mathrm{x}$ 100\%

Kontribusi Retribusi Parkir terhadap Retribusi Daerah : $\frac{\mathrm{x}}{\mathrm{y}}$ x $100 \%$

Keterangan :

$\mathrm{x}=$ Realisasi Penerimaan Retribusi Parkir

$\mathrm{y}=$ Realisasi Penerimaan Retribusi Daerah

$\mathrm{z}=$ Realisasi Penerimaan Pendapatan Asli Daerah

Tabel.2

Tingkat Presentase Kriteria Kontribusi

Presentasi Kontribusi

Kriteria Kontribusi

$0 \%-0,9 \%$

$1 \%-1,9 \%$

$2 \%-2,9 \%$

$3 \%-3.9 \%$

Lebih dari $4 \%$
Relatif tidak memiliki kontribusi

Kurang memiliki kontribusi

Cukup memiliki kontribusi

Memiliki kontribusi

Sangat memiliki kontribusi

Analisis Perhitungan Tingkat Efektivitas Retribusi Parkir 
Tingkat efektivitas retribusi parkir yang terealisasi dicari menggunakan rasio efektivitas yaitu

Efektivitas :

$\frac{\text { Realisasi Penerimaan Retribusi Parkir }}{\text { Target Penerimaan Retribusi Parkir }} \times 100 \%$.
Dengan melihat tabel
berikut yang menjelaskan tentang
Target dan Realisasi Retribusi
Parkir Tahun 2009-2013 adalah
sebagai berikut:

Tabel 3

Rekapitulasi Target dan Realisasi

Retribusi Parkir

Tahun 2009-2013

Tah Anggaran/Ta Realisasi

un rget

200 Rp. Rp.

$9 \quad 281.750 .000, \quad 223.129 .0$

$\begin{array}{ccc} & - & 00,- \\ 201 & \text { Rp. } & \text { Rp. } \\ 0 & 282.015 .000, & 259.849 .9\end{array}$

$\begin{array}{ccc} & - & 00,- \\ 201 & \text { Rp. } & \text { Rp. } \\ 1 & 400.000 .000, & 299.800 .5\end{array}$
201 Rp. Rp.
$2 \quad 410.000 .000, \quad 526.157 .5$
201 Rp. Rp.
$3 \quad 640.000 .000, \quad 700.816 .6$
$00,-$

Perhitungan :

1. Tahun 2009
Efektivitas: :

$\frac{\text { Realisasi Penerimaan Retribusi Parkir }}{\text { Target Penerimaan Retribusi Parkir }}$ X $100 \%$

: $\frac{\text { Rp. 223.129.000,-- }}{\text { Rp. 281.750.000,- }} \times 100 \%$

: 79,19\%

Jadi jika dilihat pada tabel Presentase kriteria efektivitas menunjukan bahwa tingkat efektifitas realisasi dari retribusi parkir tahun 2009 terhadap target yang dianggarkan yaitu "Kurang Efektif" dengan presentase $79,19 \%$ karena belum mencapai target yang ditetapkan oleh pemerintah dengan pencapaian kurang dari $100 \%$.

2. Tahun 2010

Efektivitas:

$\frac{\text { Realisasi Penerimaan Retribusi Parkir }}{\text { Target Penerimaan Retribusi Parkir }} \times 100 \%$

$: \frac{\text { Rp.259.849.900,- }}{\text { Rp.282.015.000,- }} \times 100 \%$

: $92,14 \%$

Jadi jika dilihat pada tabel Presentase kriteria efektivitas menunjukan bahwa tingkat efektifitas realisasi dari retribusi parkir tahun 2010 terhadap target yang dianggarkan yaitu "Efektif" dengan presentase $92,14 \%$ karena belum mencapai target yang ditetapkan oleh pemerintah dengan pencapaian kurang dari $100 \%$. 
3. Tahun 2011

Efektivitas:

$\frac{\text { Realisasi Penerimaan Retribusi Parkir }}{\text { Target Penerimaan Retribusi Parkir }} \times 100 \%$

: $\frac{\mathrm{Rp} .299 .800 .500,-}{\mathrm{Rp} .400 .000 .000,-} \times 100 \%$

: $74,95 \%$

Jadi jika dilihat pada tabel

Presentase kriteria efektivitas

menunjukan bahwa tingkat

efektifitas realisasi dari

retribusi parkir tahun 2011

terhadap target yang

dianggarkan yaitu "Kurang

Efektif" dengan presentase

$74,95 \%$ karena belum

mencapai target yang

ditetapkan oleh pemerintah

dengan pencapaian kurang dari $100 \%$.

\section{Tahun 2012}

Efektivitas:

$\frac{\text { Realisasi Penerimaan Retribusi Parkir }}{\text { Target Penerimaan Retribusi Parkir }} \times 100$ :

$\frac{\text { Rp.526.157.500,- }}{\text { Rp.410.000.000,- }} \times 100 \%$

: $128,33 \%$

Jadi jika dilihat pada tabel Presentase kriteria efektivitas menunjukan bahwa tingkat efektifitas realisasi dari retribusi parkir tahun 2011 terhadap target yang dianggarkan yaitu "Sangat Efektif" dengan presentase $128,33 \%$ karena telah mencapai target yang ditetapkan oleh pemerintah dengan pencapaian lebih dari $100 \%$.

5. Tahun 2013

Efektivitas:

$\frac{\text { Realisasi Penerimaan Retribusi Parkir }}{\text { Target Penerimaan Retribusi Parkir }} \times 100$ :

$\frac{\text { Rp.700.816.600,- }}{\text { Rp.640.000.000,- }} \times 100 \%$

: $109,50 \%$

Jadi jika dilihat pada tabel Presentase kriteria efektivitas menunjukan bahwa tingkat efektifitas realisasi dari retribusi parkir tahun 2011 terhadap target yang dianggarkan yaitu "Sangat Efektif" dengan presentase $109,50 \%$ karena telah mencapai target yang ditetapkan oleh pemerintah dengan pencapaian lebih dari $100 \%$.

1.2.2 Analisis Perhitungan Tingkat Kontribusi Retribusi Parkir Terhadap Retribusi Daerah

Tingkat Kontribusi

Retribusi Parkir Terhadap Retribusi Daerah yang terealisasi dicari menggunakan rumus yaitu

Kontribusi Retribusi Parkir terhadap Retribusi Daerah

$\frac{\text { Realisasi Penerimaan Retribusi Parkir }}{\text { Realisasi Penerimaan Retribusi Daerah }} \times 100 \%$, Dengan melihat tabel berikut yang menjelaskan tentang Penerimaan Retribusi Parkir dan Jumlah Retribusi Daerah Tahun 2009-2013 adalah sebagai berikut : 
Tabel 4

Rekapitulasi Penerimaan Retribusi Daerah dan Retribusi Parkir Tahun 2009-2013

\begin{tabular}{ccc} 
Tahun & $\begin{array}{c}\text { Retribusi Daerah } \\
\text { (Realisasi) }\end{array}$ & $\begin{array}{c}\text { Retribusi Parkir } \\
\text { (Realisasi) }\end{array}$ \\
2009 & Rp.9.323.675.310,- & Rp. 223.129.000,- \\
2010 & Rp.10.237.262.522,- & Rp. 259.849.900,- \\
2011 & Rp.11.267.458.193,- & Rp. 299.800.500,- \\
2012 & Rp.17.399.793.035,- & Rp. 526.157.500,- \\
2013 & Rp.21.593.942.764,- & Rp. 700.816.600,- \\
\multicolumn{2}{l}{ Sumber : Dispenda Kota Kupang Tahun 2014 }
\end{tabular}

Perhitungan :

1. Tahun 2009

Kontribusi

$\frac{\text { Realisasi Penerimaan Retribusi Parkir }}{\text { Realisasi Penerimaan Retribusi Daerah }} \quad \mathrm{x}$ $100 \%$

$: \frac{\text { Rp.223.129.000,-- }}{\text { Rp.9.323.675.310,-- }} \times 100 \%$

: $2,39 \%$

Jadi jika dilihat pada tabel Presentase kriteria Kontribusi menunjukan bahwa tingkat kontribusi dari retribusi parkir tahun 2009 terhadap Retribusi daerah kota Kupang tahun 2009 yaitu "Cukup memiliki kontribusi" dengan presentase $2,39 \%$, tingkat presentasi ini bisa dikatakan bahwa masih sangat kecil karena kurang dari 4\% yang merupakan standar yang paling besar $(\geq 4 \%$ masuk dalam kategori "sangat memiliki kontribusi”).

2. Tahun 2010

Kontribusi:

$\frac{\text { Realisasi Penerimaan Retribusi Parkir }}{\text { Realisasi Penerimaan Retribusi Daerah }}$ x 100\%

$$
: \frac{\mathrm{Rp} \cdot 259.849 .900,-}{\mathrm{Rp} \cdot 10.237 \cdot 262.522,-} \times 100 \%
$$$$
\text { : }: 2,54 \%
$$

Jadi jika dilihat pada tabel Presentase kriteria Kontribusi menunjukan bahwa tingkat kontribusi dari retribusi parkir tahun 2010 terhadap Retribusi daerah kota Kupang tahun 2010 yaitu "Cukup memiliki kontribusi" dengan presentase $2,54 \%$ tingkat presentasi ini bisa dikatakan bahwa masih sangat kecil karena kurang dari $4 \%$ yang merupakan standar yang paling besar $(\geq 4 \%$ masuk dalam kategori "sangat memiliki kontribusi”).

3. Tahun 2011

Kontribusi:

$\frac{\text { Realisasi Penerimaan Retribusi Parkir }}{\text { Realisasi Penerimaan Retribusi Daerah }} \mathrm{x}$ $100 \%$

: $\frac{\text { Rp.299.800.500,-- }}{\text { Rp.11.267.458.193,- }} \times 100 \%$ $: 2,66 \%$

Jadi jika dilihat pada tabel Presentase kriteria Kontribusi 
menunjukan bahwa tingkat kontribusi dari retribusi parkir tahun 2011 terhadap Retribusi daerah kota Kupang tahun 2011 yaitu "Cukup memiliki kontribusi" dengan presentase $2,66 \%$ tingkat presentasi ini bisa dikatakan bahwa masih sangat kecil karena kurang dari 4\% yang merupakan standar yang paling besar $(\geq 4 \%$ masuk dalam kategori "sangat memiliki kontribusi”).

4. Tahun 2012

Kontribusi:

$\frac{\text { Realisasi Penerimaan Retribusi Parkir }}{\text { Realisasi Penerimaan Retribusi Daerah }} \quad \mathrm{X}$ $100 \%$

: $\frac{\text { Rp.526.157.500,-- }}{\text { Rp.17.399.793.035,- }} \times 100 \%$

: $3,02 \%$

Jadi jika dilihat pada tabel Presentase kriteria Kontribusi menunjukan bahwa tingkat kontribusi dari retribusi parkir tahun 2012 terhadap Retribusi daerah kota Kupang tahun 2012 yaitu "Memiliki kontribusi" dengan presentase 3,02\% tingkat presentasi ini bisa sudah bisa dikatakan memilki kontribusi karena sudah mendekati $4 \%$ yang merupakan standar yang paling besar ( $\geq 4 \%$ masuk dalam kategori "sangat memiliki kontribusi”).

5. Tahun 2013

Kontribusi:

Realisasi Penerimaan Retribusi Parkir $\mathrm{x}$ Realisasi Penerimaan Retribusi Daerah $100 \%$

: $\frac{\text { Rp.700.816.600,- }}{\text { Rp.21.593.942.764,-- }} \times 100 \%$

: $3,25 \%$

Jadi jika dilihat pada tabel Presentase kriteria Kontribusi menunjukan bahwa tingkat kontribusi dari retribusi parkir tahun 2013 terhadap Retribusi daerah kota Kupang tahun 2013 yaitu "Memiliki kontribusi" dengan presentase $3,25 \%$ tingkat presentasi ini bisa sudah bisa dikatakan memilki kontribusi karena sudah mendekati 4\% yang merupakan standar yang paling besar $(\geq 4 \%$ masuk dalam kategori "sangat memiliki kontribusi").

Hasil perhitungan kontribusi retribusi parkir terhadap Retribusi Daerah tahun 2009-2013 diatas dapat dilihat lebih jelas pada tabel berikut ini :

Tabel 5

Hasil Perhitungan Kontribusi Retribusi Parkir Terhadap Retribusi Daerah Tahun 2009-2013 


\begin{tabular}{|c|c|c|c|c|}
\hline Tahun & Retribusi Daerah & Retribusi Parkir & $\%$ & Ket. \\
\hline 2009 & Rp.9.323.675.310,- & Rp. 223.129.000,- & $2,39 \%$ & $\begin{array}{l}\text { Cukup } \\
\text { Memiliki }\end{array}$ \\
\hline 2010 & Rp.10.237.262.522,- & Rp. 259.849.900,- & $2,54 \%$ & $\begin{array}{l}\text { Kontribusi } \\
\text { Cukup } \\
\text { Memiliki }\end{array}$ \\
\hline 2011 & Rp.11.267.458.193,- & Rp. 299.800.500,- & $2,66 \%$ & $\begin{array}{l}\text { Kontribusi } \\
\text { Cukup } \\
\text { Memiliki } \\
\text { Kontribusi }\end{array}$ \\
\hline 2012 & Rp.17.399.893.035,- & Rp. 526.157.500,- & $3,02 \%$ & $\begin{array}{l}\text { Memiliki } \\
\text { Kontribusi }\end{array}$ \\
\hline 2013 & Rp.21.593.942.764,- & Rp. 700.816.600,- & $3,25 \%$ & $\begin{array}{l}\text { Memiliki } \\
\text { Kontribusi }\end{array}$ \\
\hline
\end{tabular}

Sumber : Data di olah Tahun 2014

1.2.3 Analisis Perhitungan Tingkat Kontribusi Retribusi Parkir Terhadap Pendapatan Asli Daerah Tingkat Kontribusi

Retribusi Parkir Terhadap Retribusi Daerah yang terealisasi dicari menggunakan rumus yaitu Kontribusi Retribusi Parkir terhadap Pendapatan Asli Daerah :
Realisasi Penerimaan Retribusi Parkir

Realisasi Penerimaan Pendapatan Asli Daerah x $100 \%$

Dengan melihat tabel berikut yang menjelaskan tentang Penerimaan Retribusi Parkir dan Jumlah Pendapatan Asli Daerah Kota Kupang Tahun 2009-2013 adalah sebagai berikut :

Tabel 6

Rekapitulasi Penerimaan Pendapatan Asli Daerah dan Retribusi Parkir Tahun 2009-2013

$\begin{array}{ccc}\text { Tahun } & \begin{array}{c}\text { Pendapatan Asli Daerah } \\ \text { (Realisasi) }\end{array} & \begin{array}{c}\text { Retribusi Parkir } \\ \text { (Realisasi) }\end{array} \\ 2009 & 36.204 .733 .167,02 & \text { Rp. 223.129.000,- } \\ 2010 & 36.828 .891 .454,35 & \text { Rp. 259.849.900,- } \\ 2011 & 47.702 .927 .427,60 & \text { Rp. 299.800.500,- } \\ 2012 & 66.035 .428 .092,83,- & \text { Rp. 526.157.500,- } \\ 2013 & 80.755 .471 .988,14 & \text { Rp. 700.816.600,- } \\ \text { Sumber }: \text { Dispenda Kota Kupang Tahun 2014 }\end{array}$

Sumber : Dispenda Kota Kupang Tahun 2014 
Perhitungan: $\quad$ Kupang tahun 2010 yaitu

1. Tahun 2009

"Relatif tidak memiliki

Kontribusi: kontribusi" dengan presentase Realisasi Penerimaan Retribusi Parkir $\quad 0,71 \%$ tingkat presentasi ini Realisasi Penerimaan Pendapatan Asli Daerablapat dikatakan masih sangat $\mathrm{x} 100 \%$

: $\frac{\text { Rp.223.129.000,- }}{\text { Rp.36.204.733.167,02 }} \times 100 \%$ jauh (terlalu kecil tingkat $: 0,62 \%$

Jadi jika dilihat pada tabel Presentase kriteria Kontribusi menunjukan bahwa tingkat kontribusi dari retribusi parkir tahun 2009 terhadap Pendapatan Asli Daerah kota Kupang tahun 2009 yaitu "Relatif tidak memiliki kontribusi" dengan presentase $0,62 \%$ tingkat presentasi ini dapat dikatakan masih sangat jauh (terlalu kecil tingkat presentasinya) dari standar tingkat kontribusi yaitu $4 \%$ yang merupakan standar yang paling besar ( $\geq 4 \%$ masuk dalam kategori "sangat memiliki kontribusi").

2. Tahun 2010

Kontribusi

$\frac{\text { Realisasi Penerimaan Retribusi Parkir }}{\text { ealisasi Penerimaan Pendapatan Asli Daerah }} 100 \%$

: $\frac{\text { Rp.259.849.900,-- }}{\text { Rp.36.828.891.454,35 }} \times 100 \%$

: $0,71 \%$

Jadi jika dilihat pada tabel Presentase kriteria Kontribusi menunjukan bahwa tingkat kontribusi dari retribusi parkir tahun $2010 \quad$ terhadap Pendapatan Asli Daerah kota presentasinya) dari standar tingkat kontribusi yaitu $4 \%$ yang merupakan standar yang paling besar $(\geq 4 \%$ masuk dalam kategori "sangat memiliki kontribusi”).

3. Tahun 2011

Kontribusi

$\frac{\text { Realisasi Penerimaan Retribusi Parkir }}{\text { Realisasi Penerimaan Pendapatan Asli Daerah }} \times 100 \%$ $: \frac{\mathrm{Rp} \cdot 299.800 .500,-}{\mathrm{Rp} \cdot 47.702 .927 .427,60} \times 100 \%$

: 0,63

Jadi jika dilihat pada tabel Presentase kriteria Kontribusi menunjukan bahwa tingkat kontribusi dari retribusi parkir tahun 2011 terhadap Pendapatan Asli Daerah kota Kupang tahun 2011 yaitu "Relatif tidak memiliki kontribusi"

Tahun 2012

Kontribusi:

Realisasi Penerimaan Retribusi Parkir $\times 100 \%$

Rp.526.157.500,-

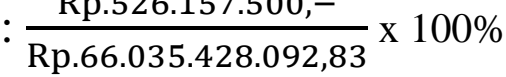

: $0,80 \%$

Jadi jika dilihat pada tabel Presentase kriteria Kontribusi menunjukan bahwa tingkat kontribusi dari retribusi parkir tahun 2012 terhadap 
Pendapatan Asli Daerah kota

Kupang tahun 2012 yaitu

"Relatif tidak memiliki kontribusi" dengan presentase $0,80 \%$.

Tahun 2013

\section{Kontribusi}

$\frac{\text { Realisasi Penerimaan Retribusi Parkir }}{\text { Realisasi Penerimaan Pendapatan Asli Daerah }}$ X $100 \%$

$: \frac{\mathrm{Rp} .700 .816 .600,-}{\mathrm{Rp} .80 .755 .471 .988,14} \times 100 \%$

: $0,87 \%$

Jadi jika dilihat pada tabel Presentase kriteria Kontribusi menunjukan bahwa tingkat kontribusi dari retribusi parkir tahun 2013 terhadap Pendapatan Asli Daerah kota
Kupang tahun yaitu "Relatif tidak memiliki kontribusi" dengan presentase $0,87 \%$ tingkat presentasi ini dapat dikatakan masih sangat jauh (terlalu kecil tingkat presentasinya) dari standar tingkat kontribusi yaitu $4 \%$ yang merupakan standar yang paling besar $(\geq 4 \%$ masuk dalam kategori "sangat memiliki kontribusi").

Hasil perhitungan kontribusi retribusi parkir terhadap Pendapatan Asli Daerah tahun 2009-2013 diatas dapat dilihat lebih jelas pada tabel berikut ini :

Tabel 7

Hasil Perhitungan Kontribusi Retribusi Parkir Terhadap Pendapatan Asli

\begin{tabular}{|c|c|c|c|c|}
\hline & \multicolumn{4}{|c|}{ Daerah Tahun 2009-2013 } \\
\hline Tahun & $\begin{array}{l}\text { Retribusi } \\
\text { Daerah }\end{array}$ & Retribusi Parkir & $\%$ & Ket. \\
\hline 2009 & $\begin{array}{c}36.204 .733 .167 \\
02\end{array}$ & Rp. 223.129.000,- & $0,62 \%$ & $\begin{array}{c}\text { Relatif tidak } \\
\text { memiliki kontribusi }\end{array}$ \\
\hline 2010 & $\begin{array}{c}36.828 .891 .454 \\
35\end{array}$ & Rp. 259.849.900,- & $0,71 \%$ & $\begin{array}{c}\text { Relatif tidak } \\
\text { memiliki kontribusi }\end{array}$ \\
\hline 2011 & $\begin{array}{c}47.702 .927 .427 \\
60\end{array}$ & Rp. 299.800.500,- & $0,63 \%$ & $\begin{array}{c}\text { Relatif tidak } \\
\text { memiliki kontribusi }\end{array}$ \\
\hline 2012 & $\begin{array}{c}66.035 .428 .092 \\
83,-\end{array}$ & Rp. 526.157.500,- & $0,80 \%$ & $\begin{array}{c}\text { Relatif tidak } \\
\text { memiliki kontribusi }\end{array}$ \\
\hline 2013 & $\begin{array}{c}80.755 .471 .988 \\
14\end{array}$ & Rp. 700.816.600,- & $0,87 \%$ & $\begin{array}{c}\text { Relatif tidak } \\
\text { memiliki kontribusi }\end{array}$ \\
\hline
\end{tabular}


Sumber : Data di olah Tahun 2014

\begin{tabular}{|c|c|}
\hline 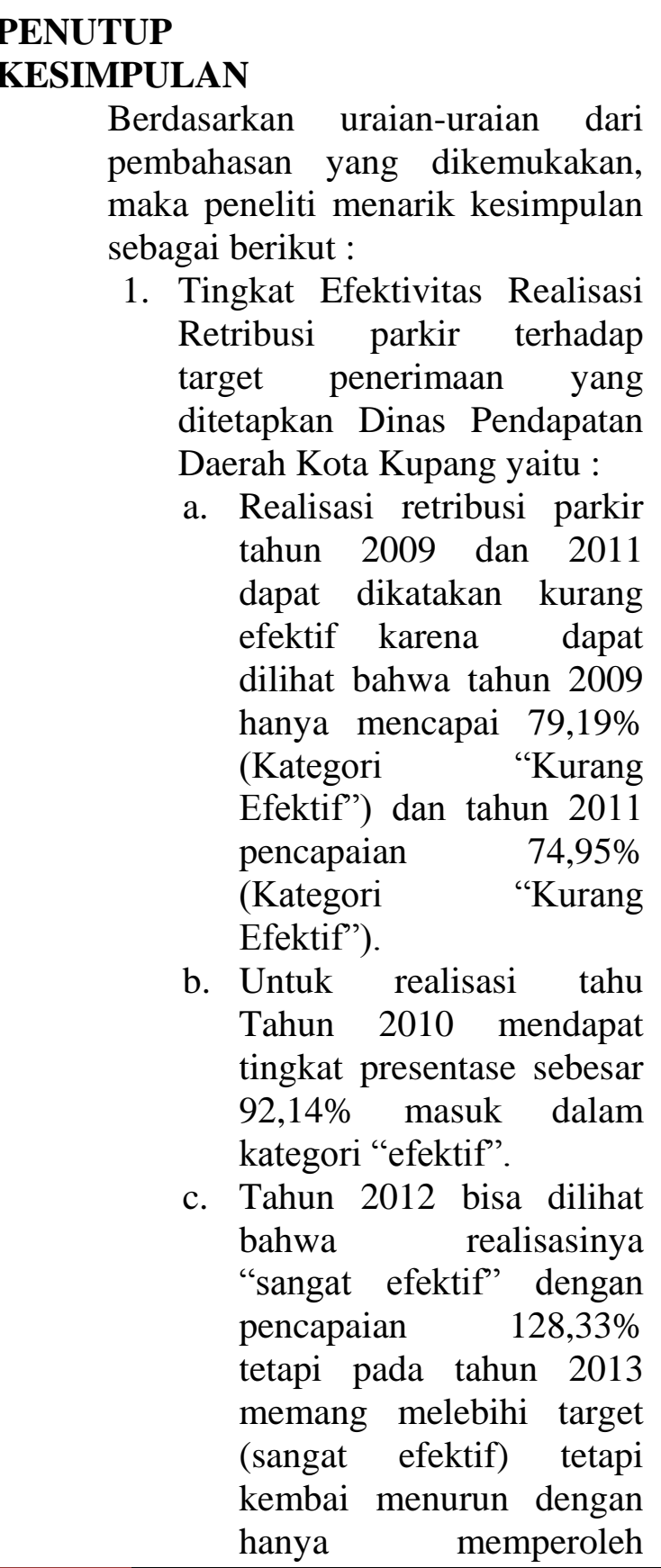 & 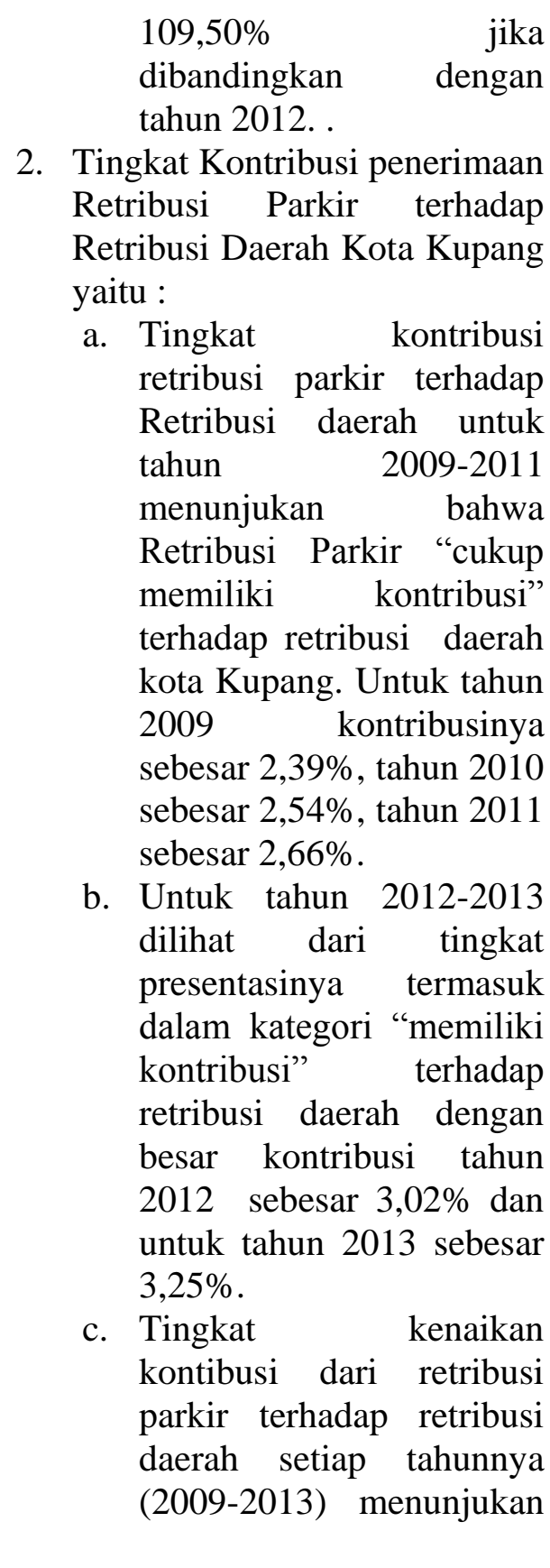 \\
\hline
\end{tabular}


hasil yang baik karena selalu meningkat.

3. Tingkat Kontribusi penerimaan Retribusi Parkir terhadap Pendapatan Asli Daerah Kota Kupang yaitu :

a. Kontribusi tahun 2010 naik menjadi $0,71 \%$ jika dibandingkan dengan tahun 2009 yang hanya $0,62 \%$, sedangkan tahun 2011 kembali menurun menjadi $0,63 \%$. Untuk tahun 2012 kembali naik dengan tingkat presentasi $0,80 \%$ dan tahun 2013 sebesar $0,87 \%$.

b. Tingkat kontribusi retribusi parkir terhadap Pendapatan Asli Kota Kupang masih sangat kecil dan masuk dalam kategori "Relatif tidak memiliki kontribusi" terhadap pendapatan asli daerah jika dilihat dari hasil perhitungan presentasinya.

\section{SARAN}

Berdasarkan kesimpulan di atas, peneliti memberi saran untuk pihak Pemerintah dalam hal ini Dinas Pendapatan Daerah Kota Kupang dan Dinas-dinas lainnya (SKPD) yang terkait dibidang retribusi parkir berupa :
1. Pemerintah dalam hal ini Dinas Pendapatan Daerah Kota Kupang dan dinas (SKPD) yang terkait dibidang retribusi parkir dapat melakukan sosialisasi kepada masyarakat tentang pentingnya membayar parkir dengan tujuan menjadi pemasukan/pendapatan untuk daerah kota kupang.

2. Pemerintah dalam hal ini Dinas Pendapatan Daerah Kota Kupang dan dinas (SKPD) yang terkait dibidang retribusi parkir lebih ketat dalam mengelola retribusi parkir di Kota Kupang, karena masih banyak Juru Parkir liar yang ada di Kota Kupang, selain itu masih ada juga lahan parkir yang belum di kelola oleh pemerintah.

3. Mendata ulang lahan parkir yang masih berpotensi menghasilkan pendapatan dalam hal ini penerimaan retribusi parkir sehingga target yang ditetapkan dapa direalisasikan dengan baik sehingga kontribusinyapun semakin besar dan Pendapatan Asli Derah yang diterima/direalisasikan pun semakin besar. 


\section{DAFTAR PUSTAKA}

B, Marselina, Ega, 2013, Analisis Kontribusi dan Efektivitas Pajak Parkir dan Retribusi Parkir Pasar terhadap Pendapatan Asli Daerah Pada Pemerintah Kota Padang, Skripsi, Padang : Program Strata 1

Bawasir, Fuad, 2000, Kontribusi dan Efektivitas, Yogjakarta, Penerbit, Alfabeta

Dahlan, M , YB, 2003, Manajemen Operasional, Jakarta, Penerbit : Lembaga Penerbit Fakultas Ekonomi Universitas Indonesia

----, Kepmendagri

No.690.900.327.1996, “ Pedoman Penilaian dan Kinerja Keuangan tahun 1997".

Guritno, T, 1992, Kamus Ekonomi, Surabaya, Penerbit, Alfabeta

Halim, Abdul, Prof, 2004, Akuntasi Keuangan Daerah, Jakarta, Salemba Empat

Hasan, Ali , 2008, Marketing, Yogyakarta, Penerbit : Media Presindo

Kuncoro Mudrajad, 2003, Metode Riset untuk bisnis dan ekonomi, Jakarta, Erlangga

Kurniawan, Agung, 2005, Transformasi Pelayanan Publik, Jakarta , Erlangga

Mahsun, Mohamad, SE,. M.Si,Ak, 2012, Pengukuran Kinerja Sektor Publik, Yogyakarta, Penerbit :BPFE YOGYAKARTA

Ndraha Taliziduhu Prof. Ir. 2005. "Kybernologi Sebuah Rekonstruksi Ilmu Pemerintahan", Jakarta,
Rineka Cipta

----, Perda Kota Kupang No. 15 , 2011, tentang Retribusi Pelayanan Parkir Ditepi jalan Bab I Pasal 1 No. 5

Rozzaq, Gazzali Ar, 2010, Kontribusi dan Efektivitas Retribusi Jasa Umum Terhadap Penerimaan Pendapatan Asli Daerah Surakarta Tahun 2005-2009, Skripsi, Surakarta : Program Strata 1

Siregar, Amri, 2009, Analisis Tingkat Efektivitas dan Kontribusi Pajak dan Retribusi Daerah Terhadap Pendapatan Asli Daerah (PAD), Skripsi, Sumatera Utara : Program Strata 1

Sufraeni, Dewi, 2010, Tinjauan Atas Efektifitas Pajak Parkir dan Kontribusinya dalam meningkatkan Pendapatan Asli Daerah Pada Dinas Pendapatan Daerah dan Pengelolaan Keuangan, Skripsi, Bandung : Program Strata 1

Sugiyanto, S, MM, 2010, Pajak dan Retribusi Daerah, Jakarta, Penerbit, Grasindo

Sugiyono, 2005, Metode Penelitian Bisnis, Bandung, Penerbit, Alfabeta

Suharyadi, dkk, 2003, Statistika untuk ekonomi dan keuangan modern, Jakarta, Penerbit, Salemba Empat

Tjiptono, Fandy, 2008, Strategi Pemasaran, Yogyakarta, Penerbit : PT ANDI Offset

Republik
Indonesia Nomor 25 tentang
Perimbangan Keuangan Antara
Pemerintah Pusat Dan Daerah,
1999


